\title{
The Philosophical Dimensions of the Doctrine of Unconscionability
}

\author{
Philip Bridwell $\dagger$
}

The doctrine of unconscionability permits courts to invalidate contracts that they deem to be fundamentally unfair. Section 2-302 of the Uniform Commercial Code (UCC),' which embodies this doctrine, is one of the Code's most controversial provisions. ${ }^{2}$ By 1967 , only 16 years after the first official version of the Code appeared, over 130 articles had been published on the doctrine of unconscionability. Many of the articles published in the 1960 s were aimed at providing guidance to courts applying the unconscionability doctrine. However, in 1970, Robert Braucher, author of the UCC's provisions concerning unconscionability, remarked that "we are probably not much more ready now than we were twenty years ago to arrive at comprehensive reasoned elaboration of what is unconscionable.... We may not have added much to the old saw, 'A fair exchange is no robbery.",

Braucher's remark raises two important questions. First, why after nineteen years and well over one hundred law review articles did legal scholars feel that they were unable to provide courts with a "rea-

$\dagger$ B.A. 1998, University of Pennsylvania; J.D. 2003, The University of Chicago.

1 UCC $\$ 2-302$ (ALI 2003) provides:

(1) If the court as a matter of law finds the contract or any clause of the contract to have been unconscionable at the time it was made the court may refuse to enforce the contract, or it may enforce the remainder of the contract without the unconscionable clause, or it may so limit the application of any unconscionable clause as to avoid any unconscionable result.

(2) When it is claimed or appears to the court that the contract or any clause thereof may be unconscionable the parties shall be afforded a reasonable opportunity to present evidence as to its commercial setting, purpose and effect to aid the court in making the determination.

2 See Robert Braucher, The Unconscionable Contract or Term, 31 U Pitt L Rev 337, 337 (1970).

3 See Arthur Allen Leff, Unconscionability and the Code-The Emperor's New Clause, 115 U Pa L Rev 485, 486 n 3 (1967).

4 See, for example, id at 488 (distinguishing between problems in the bargaining process. or "procedural unconscionability," and problems in the outcome of the bargaining process, or "substantive unconscionability"); John E. Murray, Jr., Unconscionability: Unconscionability, $31 \mathrm{U}$ Pitt L Rev 1, 14 (1969) (proposing three criteria that courts should consider to ascertain parties' reasonable expectations); Richard E. Speidel, Unconscionability, Assent and Consumer Protection, 31 U Pitt L Rev 359, 368-69 (1969) (proposing that the more sophisticated party should bear the burden of demonstrating a contract's reasonableness in consumer transactions irrespective of consumer assent).

5 Braucher, 31 U Pitt L Rev at 347 (cited in note 2). 
soned elaboration of what is unconscionable"? Second, what effect did this scholarly inability have on the application of the doctrine? This Comment addresses both of these questions. More importantly, this Comment argues that the doctrine of unconscionability should be defined solely by reference to external factors that may prevent parties from making free choices. Such a definition would allow courts to elucidate what is and is not unconscionable in a coherent manner.

In making this argument, this Comment suggests that legal scholars have been unable to provide courts with a clear understanding of unconscionability because authors have failed to examine the connection between unconscionability and philosophy.' Rather, scholars uniformly describe unconscionability as an ambiguous and undefinable concept. ${ }^{\mathrm{B}}$ The philosophical dimension of unconscionability is important because the debate over Section 2-302 reflects an underlying disagreement over two concepts of liberty." The first concept, which phi-

6 Id. The definition of unconscionability remains a controversial subject among legal scholars. In the 1994 Coase lecture at the University of Chicago Law School, Richard Craswell cited the contract clauses litigated in two seminal unconscionability cases decided in the 1960s as examples of "some of the more controversial limits on the enforceability of contract terms." See Richard Craswell, Freedom of Contract, in Eric A. Posner, ed, Chicago Lectures in Law and Economics 81,82 (Foundation 2000) (referring to "a clause that gives a creditor the right to repossess all of the debtor's furniture if the debtor misses a payment" and "a clause that releases a manufacturer from all liability . . if its product turns out to be defective"), citing Williams $v$ Walker-Thomas Furniture Co, 350 F2d 445 (DC Cir 1965), and Henningsen v Bloomfield Motors, Inc, 32 NJ 358, 161 A2d 69 (1960). The enforceability of these types of clauses remains controversial because scholars have not agreed on what is and what is not unconscionable.

7 Few pieces of legal scholarship make reference to the connection between unconscionability and philosophy. Consider John D. Calamari and Joseph M. Perillo, The Law of Contracts \$ 9-40 at 406 (West 3d ed 1987) ("[Unconscionability] is a term borrowed from moral philosophy and ethics."). Unfortunately, Calamari and Perillo do not elaborate on the potential ramifications of this connection. Although some legal scholars argue that unconscionability should be understood in light of a particular philosophical tradition, they do not examine the origins of, or the inherent philosophical problems with, the doctrine. See, for example, Robert Wisner, Understanding Unconscionability: An Essay on Kant's Legal Theory, 51 U Toronto Fac L Rev 396, 398 (1993) (arguing that unconscionability should be understood in light of Kantian philosophy).

8 See John A. Spanogle, Jr., Analyzing Unconscionability Problems, 117 U Pa L Rev 931, 931 (1969) ("The primary problem with this all-purpose weapon is that the concept of unconscionability is vague."); M.P. Ellinghaus, In Defense of Unconscionability, 78 Yale L J 757 , 758 (1969) (arguing that it is "inappropriate" to try to define unconscionability); Symposium, Unconscionability: An Attempt at Definition, 31 U Pitt L Rev 333,333 (1970) ("Unconscionability seems to be an amorphous concept incapable of exact definition."); Leff, $115 \mathrm{U}$ Pa L Rev at 488 (cited in note 3) (arguing that the concept of unconscionability presented in \$ 2-302 is an "amorphous unintelligibility"). See also Note, Section 2.302 of the Uniform Commercial Code: The Consequences of Unconscionability in Sales Contracts, 63 Yale L J 560, 560 n 2 (1954) ("The vague nature of the standard [for determining whether specific performance of a contract will be ordered] is increased because there has never been an adequate definition of an 'unconscionable contract."); Calamari and Perillo, The Law of Contracts $\$ 9-40$ at 406 (cited in note 7) ("'Unconscionable' is a word that defies lawyer-like definition.").

9 Consider, for example, the argument that the doctrine of unconscionability was needed to "reconcile the principle of freedom of contract with the necessity to assault directly the unfairness of standard and adhesion contracts." Sinai Deutch, Unfair Contracts: The Doctrine of 
losophers describe as positive freedom, aims to enable people "to do what they would do if they knew enough, or were always at their best, instead of yielding to irrational motives." The second concept of liberty, which is classified by philosophers as negative freedom, attempts to preserve a sphere of individual autonomy within which an individual can make his own decisions without assistance or interference."

Many courts have relied on a positive conception of freedom to support the application of Section 2-302. As this Comment will show, however, positive freedom is not a sound basis for application of the doctrine of unconscionability. This stems from the fact that positive freedom defines "free choice" with reference to the "reasonableness" of the choice. However, there are intractable philosophical difficulties associated with the idea that freedom is contingent on the use of reason. These difficulties prevent both courts and scholars from developing a coherent account of unconscionability. This Comment proposes that the doctrine of unconscionability should rely on a negative conception of freedom. Negative freedom, in contrast to positive freedom, defines free choice solely by reference to external factors rather than examining the reasonableness of the choice. Under this concept of freedom, a court's inquiry into whether the transaction was voluntary would be limited to determinations of whether external factors improperly affected the transaction.

\section{THE CONCEPT OF THE WILL IN CONTRACT LAW}

The will theory of contract holds that "free will" is necessary for assent to be present and hence for a contract to be enforceable. An examination of the acceptance of the will theory in contract law during the nineteenth century illustrates that the will theory does not rely on a particular substantive conception of the will-that is, a concept of the will that specifies when the will is free. The absence of a substantive theory of the will is central to understanding the problems presented by the doctrine of unconscionability because this absence en-

Unconscionability 20 (Lexington 1977). This description indicates that two concepts of liberty are at issue in the debate over unconscionability: first, the liberty embodied in the traditional concept of freedom of contract; and second, the liberty upon which standard-form contracts are infringing.

10 Ted Honderich, ed, The Oxford Companion to Philosophy 486 (Oxford 1995).

11 See id. The boundaries of this sphere of individual autonomy are commonly described in terms of a collision of rights: My rights end where your rights begin. It is often pointed out, however, that this formulation fails to specify precisely where my rights end and yours begin. For purposes of this debate, it should be understood that negative freedom requires a direct causal connection for an act to constitute a violation of another person's freedom. Negative freedom would therefore view a punch in the face as a violation of your freedom but would not view a disparity in material resources between you and other individuals as a constraint on your freedom. 
ables legal scholars to answer the question of whether free choice is present by appealing to different concepts of freedom-specifically, positive and negative freedom.

The story of how the concept of the will first entered into contract law helps explain why will theory lacks a substantive conception of the will and also shows how the doctrine of unconscionability ultimately came to be based on positive freedom. In Part A, I examine the concept of the will in contract theory. I conclude that the will theory is not predicated on a particular substantive conception of the will. Deciding upon a substantive conception of the will would set limits on parties' contracting power and thus provide guidelines to courts in analyzing whether a party has made a free choice and hence whether a contract was unconscionable. In Part B, I examine the concept of the will advanced by positive freedom. I conclude that this concept of the will presents intractable philosophical difficulties that have precluded the development of a coherent concept of unconscionability.

\section{A. The Rise of the Will Theory of Contract}

During the Middle Ages, contract law relied on ritualistic formalities to give agreements legal force. ${ }^{12}$ However, as the secular power of the church declined, the quasi-religious formalities associated with contract formation declined in importance. By the nineteenth century, human will, rather than ritual, gave contracts their legally binding character. ${ }^{13}$ The reliance on the will in contract law was not an entirely new innovation: Human will had long been seen as a means through which one could make a legally binding contract. ${ }^{\text {t. }}$ The innovation of nineteenth-century will theorists was not their reliance on the concept of the will to give a contract its legally binding force, but rather their

12 The reliance on ritual was the product of the strong connection between contract and religion during the Middle Ages. See Larry A. DiMatteo. Contract Theory: The Evolution of Contractual Inten 76 (Michigan State 1998) ("Contract was in essence a type of sacrament much like that of marriage or baptism.... It was the words of the contractual ceremony or oath that provided the vehicle for the creation of a binding. enforceable bond.").

13 Id ("[T]he manifestation of will can be seen as the modern-day counterpart to the solemn or ritual contract."). For a further discussion on the rise of the will theory in the nineteenth century. see Samuel Williston. Freedom of Contract, 6 Cornell L Q 365. 368-72 (1921).

14 Prior to the rise of the will theory of contract in the nineteenth century, contracts such as sale. lease, agency, and partnership were enforced solely because the parties had expressed their will to be bound by them. See James Gordley. Contract. Property, and the Will-The Civil Law and Common Law Tradition, in Harry N. Scheiber, ed. The State and Freedom of Contract 66.68 (Stanford 1998). In addition. since the thirteenth century, certain feudal interests in property. such as the fee simple, were freely alienable and required only an expression of the parties" will. See A.W.B. Simpson. Land Ownership and Economic Freedom. in Scheiber, ed. State and Freedom of Contract 13.22. 
reliance on "that concept exclusively, without introducing any other concept that could limit what legitimately could be willed."

The reliance on the will of the parties as the sole factor limiting contractual enforcement focused the courts' inquiry on the question of whether free will was present. However, the concept of the will introduced by the will theorists during the nineteenth century failed to specify the circumstances in which free will was present. That is, will theorists did not accept a particular substantive conception of the will.

Two aspects of the debate support this contention. First, there was relatively little debate over the will theory during the nineteenth century; jurists and scholars embraced the will theory with little discussion. This is surprising because freedom of the will is one of the most widely debated issues among philosophers ${ }^{17}$ and has recently been characterized as "arguably the most difficult [problem] ... in philosophy." As a result, a will theory of contracts predicated on a particular substantive conception of the will would likely have engendered a significant amount of debate.

Second, there continues to be a significant amount of debate among contract law scholars over the criteria necessary to determine whether a choice was freely made." While legal scholars are in agreement that man possesses free will and that free will is necessary to form an enforceable contract, they do not agree on criteria to determine whether the will is free in a particular situation. ${ }^{21}$ The absence of

15 Gordley. Contract, Property, and the Will at 70 (cited in note 14) (emphasis added).

in Id at 73-79 (noting that unlike "other intellectual movements that stressed individual choice." which "were the subject of endless disputes." the will theories "enjoyed an easy and universal acceptance").

17 See Wallace I. Matson. 1 A New History of Philosophy: Ancient \& Medieval 158 (Harcourt Brace Jovanovich 1987) (stating that freedom of the will is "perhaps the most voluminously debated of all philosophical problems“).

I8 Robert Kane. The Significance of Free Will 3 (Oxford 1996), quoting Susan Wolf. Freedom within Reason vii (Oxford 1990).

19 See the discussion of Richard Epstein's criticism of John Dawson's claim about the relationship between freedom of the will and duress in Part I.B.

20) Compare the views of John Dalzell and Charles Fried on the question of free will. Dalzell argues that a promise made under duress is unenforceable not because the persons did not exercise free will in consenting to the contract. but because of the impropriety of the alternative. See John Dalzell. Duress by Economic Pressure I. 20 NC L Rev 237. 238 (1942) (asserting that consent given under duress is "real" consent. in that the actor truly prefers the chosen alternative above all other alternatives, but that certain sets of alternatives are too unappealing to give rise to enforceable agreements). In contrast, Charles Fried asserts, "A promise given under duress. though knowingly made, is not freely made." Charles Fried, Contract as Promise: A Theory of Contractual Obligation 92 (Harvard 1981). The difference between these two understandings of free will can be understood by examining the connection between free will and morality in each author's argument. Fried subsumes the moral dimension of choosing into the concept of free will. He therefore reaches the conclusion that the will can be free only when making morally acceptable choices. Dalzell divorces the exercise of free will from the moral content of the choices presented and therefore argues that free will is present even in cases where one of the choices offered is repugnant. Thus, while each author agrees with the idea that man has free will and that 
an internal rationale for limiting contractual freedom allows scholars to draw on different - and often disparate - philosophical traditions to determine when free choice exists.

Not surprisingly, legal scholars continue to offer varied definitions of free choice. To illustrate this point, compare James Gordley's understanding of contract law, which draws heavily on the philosophy of Aristotle, with Charles Fried's theory of contract law, which is based on the philosophy of Kant. While both employ a distinct substantive theory of the will," each relies on the teaching of a different philosopher to specify when a choice is freely made. In doing so they create an internal rationale that limits contractual freedom. The fact that Gordley and Fried are able to rely on different philosophers to explain their respective visions of contract law indicates that no substantive conception of the will dominates contract law.

Because courts often invalidate contracts under Section 2-302 on the ground that free choice was not present, ${ }^{22}$ the will theorists' failure to elucidate what constitutes a free choice makes the standard for judging unconscionability unstable. The effects of this failure, however, were not fully evident until the twentieth century. The absence of a coherent account of free will was not problematic during the nineteenth century because common law courts were reluctant to void contracts when a perceived sense of inequality, as opposed to outright fraud, was the only defect. ${ }^{23}$ This reluctance can be explained by the widespread acceptance of a view of contractual freedom that was predicated on an expansive conception of individual rights. This conception of freedom attempted to demarcate a sphere within which the individual could act without interference by the state. The laissez-faire

free will is necessary to form a contract, the authors disagree over whether free will is present in the case of duress.

21 Compare James Gordley, The Philosophical Origins of Modern Contract Doctrine 161 (Oxford 1991) (noting that even as recognition of the philosophical foundations of contract law diminished. "[o]ne of the key concepts ... retained was that of the will of the contracting parties" with its "original Aristotelian meaning"), with Fried, Contract as Promise at 106-10 (cited in note 20) (noting that honoring the will of contracting parties is consistent with Kantian liberalism).

22 See, for example, Kugler v Romain. 58 NJ 522. 279 A2d 640.652 (1971) ("The intent of [Section 2-302] is not to erase the doctrine of freedom of contract. but to make realistic the assumption of the law that the agreement has resulted from real bargaining between parties who had freedom of choice.") (emphasis added).

23 See Richard A. Epstein. Unconscionability: A Critical Reappraisal, 18 J L \& Econ 293. 293 (1975) (noting that "[t]he classical conception of contract at common law had as its first premise the belief that private agreements should be enforced in accordance with their terms" unless fraud, duress, or undue influence was present). See also Robert A. Hillman, The Richness of Contract Law: An Analysis and Critique of Contemporary Theories of Contract Law 9 (Kluwer 1997) ("Nineteenth-century politicians and theorists ... came to believe that individual freedom was both a natural and moral right and that 'laissez faire' would best enable people to achieve their potential."). 
policies of the nineteenth and early twentieth centuries reflect this concept of freedom.

It is clear from both commentary and case law that the traditional common law understanding of freedom of contract is based on a concept of individual liberty that is consistent with the concept of "negative" freedom. ${ }^{24}$ For example, modern scholars describe the nineteenth-century understanding of freedom of contract in almost the same terms as philosophers describe the concept of negative freedom. ${ }^{25}$ Furthermore, both the common law defenses to contractual enforcement ${ }^{26}$ and negative freedom define free choice by reference to external rather than internal obstacles. ${ }^{27}$ This concept of freedom cabined the courts' ability to invalidate contracts by limiting the available bases for invalidation to external factors.

The courts' reluctance to invalidate contracts was altered in the early twentieth century by the growing belief that industrialization required a more active policing of contracts. Legal scholars in the United States began to argue that industrialization and the increasing use of standard-form contracts had altered the balance of power between buyer and seller to the point that the ideal of freedom of contract was no longer capable of protecting buyers' personal liberty in a

24 The idea that freedom of contract is synonymous with free will is reflected in journal articles that criticize the widespread application of unconscionability. Consider, for example, Epstein, $18 \mathrm{~J} \mathrm{~L} \mathrm{\&} \mathrm{Econ} \mathrm{at} \mathrm{305-15} \mathrm{(cited} \mathrm{in} \mathrm{note} \mathrm{23)} \mathrm{(arguing} \mathrm{that} \mathrm{courts} \mathrm{should} \mathrm{only} \mathrm{invalidate} \mathrm{con-}$ tracts where there is procedural rather than substantive unconscionability); Comment, Policing Contracts under the Proposed Commercial Code, 18 U Chi L Rev 146, 147-49 (1950) (arguing that courts need some method to determine "fair" risk allocations in order to avoid infringing on parties' right to contract).

25 Compare Harry N. Scheiber, Introduction, in Scheiber, ed, State and Freedom of Contract 1,2 (cited in note 14) (describing the traditional view of freedom of contract as the "freedom of the individual from arbitrary and capricious authority over persons or property, and the freedom to produce and to exchange goods and services"), quoting Richard W. Davis, Series Foreword, In Scheiber, ed, State and Freedom of Contract v, vi (cited in note 14), with F.A. Hayek, Freedom and Coercion, in David Miller, ed, Liberty 80,81 (Oxford 1991) (describing negative freedom as the "independence of the arbitrary will of another"). The important point on which both the nineteenth-century understanding of freedom of contract and the concept of negative freedom agree is that there must be a clearly demarcated area of individual autonomy.

26 Fraud, duress, and undue influence are examples of common law doctrines that precluded contractual enforcement.

27 The common law defenses of fraud, duress, and undue influence allowed courts to invalidate a contract or clause only when there was external coercion. For example, the claim of duress is best characterized by the situation where one party has a gun to the other's head and makes the offer of "your money or your life." See Epstein, $18 \mathrm{~J} \mathrm{~L} \mathrm{\&} \mathrm{Econ} \mathrm{at} 295$ (cited in note 23) (describing duress as a situation where one party uses "force or the threat thereof in order to procure [the other party's] consent"). The negative conception of liberty makes the further distinction between external obstacles that are the product of human agency and those that are the product of physical circumstances. Isaiah Berlin contends that only human actions constitute coercion. See Isaiah Berlin, Two Concepts of Liberty, in Miller, ed, Liberty 33, 34 (cited in note 25) (stating that coercion is "the deliberate interference of other human beings within the area in which I could otherwise act"). Thus negative freedom would consider a gun to one's head as coercive, but would not characterize the lack of financial resources to comparison shop as coercive. 
meaningful sense. ${ }^{28}$ In their critiques of standard-form contracts, ${ }^{29}$ legal scholars employed a new concept of personal liberty: "positive" freedom." Under this concept of freedom, both external and internal obstacles (for example, lack of reason) could impede free choice. This development had two important effects. First, it enabled courts to invalidate contracts in a wide variety of circumstances. Second, and more importantly, it gave the courts a significantly greater amount of discretion over the relevant criteria to judge when free choice had been violated and hence when a contract was unenforceable. The connection between reason and freedom fueled the idea that courts were increasing rather than decreasing freedom by invalidating contracts. As a result, legal scholars, relying on the concept of positive freedom, began to reject concepts that limited courts' discretion in invalidating contracts."

\section{B. Positive Freedom's Conception of the Will}

The tension between positive and negative freedom stems from the equation of free choice and reason under positive freedom. Similarly, the problems resulting from courts' application of the doctrine of unconscionability are a product of the conception of the will advanced

28 Nathan Issacs's comment that the attack on standard-form contracts was premised on the idea that "[f]reedom of contract is not synonymous with liberty" illustrates the departure from the tenet of negative freedom that equated freedom of contract and personal liberty. See Nathan Isaacs, The Standardizing of Contracts, 27 Yale L J 34, 47 (1917). Karl Llewellyn argued that disparate power applied to otherwise benign standard-form contracts can "press to the point where contract may mean rather fierce control." Karl N. Llewellyn, What Price Contract? - An Essay in Perspective, 40 Yale L J 704, 732 (1931). See also Albert A. Ehrenzweig, Adhesion Contracts in the Conflict of Laws, 53 Colum L Rev 1072, 1088-89 (1953) (discussing the increasing dangers of standard-form contracts); Leff, $115 \mathrm{U} \mathrm{Pa} \mathrm{L} \mathrm{Rev} \mathrm{at} 505 \mathrm{n} 68$ (cited in note 3) (remarking on the numerous law journal articles that examined the need to protect individuals from standard-form contracts).

29 The critique of standard-form contracts is informative because the same concerns that precipitated the attack on standard-form contracts also animated the courts' application of the doctrine of unconscionability. In all of the cases since the promulgation of Section 2-302, no court has declared unconscionable any contract term that was not standard. See W. David Slawson, Binding Promises: The Late 20th-Century Reformation of Contract Law 142 (Princeton 1996).

30) In 1917, the distinction between positive and negative freedom appeared in Isaacs's article in the Yale Law Journal discussing the problems with the standardization of contracts. See Isaacs, 27 Yale L J at 47 (cited in note 28). Unfortunately, by the mid-1960s, the problems with standard-form contracts were no longer discussed in these terms. During the $1960 \mathrm{~s}$, the debate over standard-form contracts focused solely on social policy rather than on the philosophical concepts of liberty. See, for example, J. Skelly Wright, The Courts Have Failed the Poor, NY Times 26, 101-02 (Mar 9,1969) (discussing the role of the court in ameliorating the plight of the poor and using the case of Williams $v$ Walker-Thomas Furniture as an illustration).

31 See, for example, Issacs, 27 Yale L J at 47 (cited in note 28) (arguing that governmental intervention with private contracts "clashes, of course, with the ideal of individual freedom in the negative sense of "absence of restraint" or laissez faire," but noting that "freedom in the positive sense of presence of opportunity is being served by social interference with contract"). 
by positive freedom. When using a conception of will associated with positive freedom, courts are unable to provide the necessary elements that would allow future courts to police contracts in a principled manner.

The equation of free choice with reason under positive freedom has two important corollaries. First, it implies that there are two parts to the will - the rational, "real self" and the inauthentic or "irrational self." Second, it posits that freedom is present only by adhering to the dictates of the real or rational self. The idea that freedom requires adherence to the dictates of reason raises intractable philosophical difficulties that prevent positive freedom from providing a coherent account of when a choice is freely made. These difficulties can be elucidated by examining the origins of the modern debate over free will.

The modern debate over free will opened in the late seventeenth century with the dispute between Thomas Hobbes and Bishop John Bramhall over whether free will was compatible with determinism. ${ }^{32}$ Determinism refers to a wide spectrum of philosophical positions all of which boil down to the proposition that every event is the result of pre-existing conditions that are beyond our control. ${ }^{33}$ The precepts of determinism conflict with the concept of free will because the idea that all events are determined by pre-existing conditions appears to leave little or no room for the role of the individual as a causal agent.

Hobbes argued that free will is compatible with determinism. He reached this conclusion by defining freedom as absence of physical restraint or coercion. ${ }^{34}$ Hobbes's understanding of freedom is consistent with negative freedom because both focus on external impediments that prevent free choice. Not everyone was willing to accept Hobbes's argument. Bramhall responded that Hobbes's conception of freedom was radically incomplete. It is "a brutish liberty ... such [ ] as a bird has to fly when her wings are clipped."," Freedom for Bramhall required two elements: (1) the ability to do what one intends or desires and (2) the power to determine in some ultimate way one's own purposes. . While Bramhall's first element corresponds to Hobbes's definition of freedom - that is, the ability to act in accordance with one's desires-his second requirement can perhaps best be described as

32 See Kane, Significance of Free Will at 10 (cited in note 18) (noting that in the HobbesBramhall debate, Hobbes "developed a line of argument against traditional accounts of free will that has become standard in the modern era").

33 For a discussion of determinism, see Robert Kane, Introduction: The Contours of Contemporary Free Will Debates, in Robert Kane, ed, The Oxford Handbook of Free Will 3, 5-6 (Oxford 2002).

34 Thomas Hobbes, 5 The English Works of Thomas Hobbes of Malmesbury 51-53 (Scientia 1966) (William Molesworth, ed).

35 John Bramhall, 4 The Works of John Bramhall 29 (John Henry Parker 184'4).

36 See Kane, Significance of Free Will at 11 (cited in note 18). 
"reason." Bramhall's concept of freedom therefore corresponds with positive freedom in that both require reason for free choice to exist.

Philosophers have been unable to translate Bramhall's two criteria into a coherent definition of freedom. ${ }^{37}$ This inability reveals the central philosophical difficulty of positive freedom: its inability to articulate when free will is present. Once this difficulty is taken into account, it is clear why legal scholars have failed to provide courts with "reasoned elaboration of what is unconscionable." Consider Richard Epstein's criticism of John Dawson's argument that the common law defenses to contractual enforcement are all based on a general concern about freedom of the will. ${ }^{34}$ Epstein criticizes Dawson's argument as incomplete, arguing that "[i]t is a mistake to assert that the law of duress is designed to protect 'freedom of the will' without specifying those things from which it should be free." An examination of the philosophical difficulties associated with Bramhall's understanding of freedom suggests that Dawson failed to specify "those things" from which the will should be free because such an enumeration is impossible due to positive freedom's reliance on a connection between reason and free choice.

Because the courts' application of unconscionability turns on the question of whether free will was present, the inability to provide a definition of free will creates a substantial amount of uncertainty. The inability to define with any degree of precision when a choice is freely made is problematic because this leaves the judge in a position to impose his own arbitrary conception of fairness. Part II examines the courts' application of the doctrine of unconscionability and explores the problems created by the inability to accurately define free choice.

\section{The Courts' ApPlicAtion of SECTION 2-302}

Courts have relied on positive freedom to justify their application of Section 2-302. Under positive freedom, free choice is dependent on the presence of material entitlements and the reasonableness of the choice. Positive freedom's inability to formulate a coherent conception of free choice causes courts to rely on intuitive notions of fairness in judging contracts under Section 2-302. This reliance on intuition,

37 Robert Kane notes a series of arguments for the proposition that "incompatibilist accounts cannot in principle be made intelligible." Robert Kane, Two Kinds of Incompatibilism, 50 Phil \& Phenomenological Rsrch 219, 220 (1989). Kane equated the will's ability to control itself with Baron Von Münchhausen's ability to pull himself out of a ditch using his bootstraps. Robert Kane, Free Will and Values 11 (SUNY 1985).

38 Braucher, 31 U Pitt L Rev at 347 (cited in note 2).

39 See John P. Dawson, Economic Duress - An Essay in Perspective, 45 Mich L Rev 253, 256 (1947).

40 Epstein, $18 \mathrm{~J} \mathrm{~L} \&$ Econ at 297 (cited in note 23). 
which is a product of the intractable philosophical difficulties associated with the concept of the will as defined by positive freedom, is the source of the confusion about the appropriate application of the doctrine."

\section{A. Positive Freedom and the Courts}

The judicial application of Section 2-302 was shaped by the positive conception of liberty that emerged to challenge the perceived imbalance of power between the buyer and seller that accompanied the rise of the modern industrial state. Three observations support this contention. First, the courts applying Section 2-302 consistently questioned whether the traditional common law concept of freedom of contract was capable of protecting the consumer. Second, in deciding whether to invalidate a contract under Section 2-302, courts consistently referred to the tension between the traditional common law understanding of freedom of contract and the stated purpose of Section 2-302, which required courts to actively question the validity of contracts based on the admittedly vague standard of unconscionability."

Finally, and perhaps most persuasively, positive freedom is able to explain applications of the doctrine that have puzzled some scholars. Consider the suggestion by Robert Braucher that "add-on" clauses," such as those in Williams v Walker-Thomas Furniture Co, "should be held unconscionable in any contract for the purchase of consumer

41 See Samuel Williston, 8 A Treatise on the Law of Contracts $\$ 18.2$ at 9 (West 4th ed 1998) (Richard A. Lord, ed) ("Three of the most significant cases to have adopted the principle of unconscionability embodied in the Uniform Commercial Code [Section 2-302] were decided before the Code went into effect.").

42 Consider Henningsen v Bloomfield Motors, Inc, 32 NJ 358, 161 A2d 69, 84, 86 (1960) (stating that "the basic tenet of freedom of competent parties to contract is a factor of importance" but noting that "in the framework of modern commercial life and business practices, such rules cannot be applied on a strict, doctrinal basis," because "in present-day commercial life the standardized mass contract has appeared" and "is used primarily by enterprises with strong bargaining power and position").

43 Consider Carlson v Hamilton, 8 Utah 2d 272,332 P2d 989, 990-91 (1958) (noting the tension between the idea that "people should be entitled to contract on their own terms" and the idea that courts should invalidate a contract "where it turns out that one side or the other is to be penalized by the enforcement of the terms of a contract so unconscionable that no decent, fairminded person would view the ensuing result without being possessed of a profound sense of injustice"). See also Williams v Walker-Thomas Furniture Co, 350 F2d 445, 450 (DC Cir 1965) (Danahar dissenting) (arguing that courts should take "a cautious approach" when applying Section 2-302 because "the law for so long has allowed parties such great latitude in making their own contracts").

44 An "add-on" clause allows the retailer to maintain an unpaid balance on each item purchased under an installment contract until the last item purchased is paid in full. As a result, in the event of default on any item, the retailer may repossess all of the items. See Epstein, $18 \mathrm{~J} \mathrm{~L} \mathrm{\&}$ Econ at 306 (cited in note 23 ).

$45 \quad 350$ F2d 445 (DC Cir 1965). 
goods not expected to produce money income for the consumer." The dissent in Williams made a similar distinction between luxury goods and income-producing goods." Richard Epstein characterized this distinction as groundless: "No reason is given why goods that are purchased for pleasure should be treated differently from those purchased for the production of income.... [I]t is difficult to see what justification could be offered." The justification is clear once positive freedom's concern with maintaining a "fair" balance of material possessions among segments of the population is taken into account. These distributive concerns respect individual choice only to the extent that it preserves future autonomy. The inquiry into the character of the goods at issue is an understandable outgrowth of this interest in preserving a fair share of entitlements among individuals. The ability of positive freedom to explain this suggestion indicates that the courts' application of Section 2-302 is based on a positive conception of freedom.

\section{B. Positive Freedom and Section 2-302}

1. Free choice as constrained by entitlements.

In Henningsen $v$ Bloomfield Motors, Inc, the court held that a disclaimer of warranty on a new car was unconscionable. In reaching this conclusion the court noted that the ordinary buyer has "no real freedom of choice" and offered two observations to support this contention." The court first noted that there was no variation among the warranty terms offered by the major car manufacturers in the market for new cars. The court next asserted that a car is a "necessary adjunct of daily life." The idea that cars are a necessity implies that free choice is contingent on the presence of certain material entitlements. While proponents of negative freedom would concede that certain items are necessary for free choice, ${ }^{s 2}$ the Henningsen court's inclusion

46. Braucher. $31 \mathrm{U}$ Pitt L Rev at 343 (cited in note 2).

47 The dissent argued that courts, armed with the power to invalidate contracts that are substantively unfair, would fail to make the distinction between these two types of goods. "What is a luxury to some may seem like an outright necessity to others. . . A washing machine. e.g., in the hands of a relief client might become a fruitful source of income." Williams. 350 F2d at 450 (Danahar dissenting).

48 Epstein. $18 \mathrm{~J} \mathrm{~L} \&$ Econ at $306-07$ n 36 (cited in note 23).

4932 NJ 358,161 A2d 69 (1960).

50) Id at 95 .

51 Id at 85 .

52. Although F.A. Hayek concedes that some material resources are necessary under a negative conception of freedom. his concession limits the realm of possible "necessities" to little more than food and water. Hayek. Freedom and Coercion at 91-92 (cited in note 25) (noting that "it is only in very exceptional circumstances that the sole control of a service or resource which is essential to us would confer upon another the power of true coercion" and employing the exam- 
of cars within this universe is problematic because it fails to clearly demarcate any limits as to what qualifies as a necessity. As a result, later courts are left with little guidance over whether the contract in question involves goods or services that qualify as necessities and therefore merit heightened judicial inquiry into whether free choice was present.

Williams illustrates this failure to limit what qualifies as a necessity. In Williams, the court held that an "add-on" clause in an installment contract for the sale of furniture was unconscionable. Judge Skelly Wright argued in an article shortly thereafter that the poor have "little real choice" in making such contracts because they have "little bargaining power." $\mathrm{His}$ treatment of "welfare benefits as rights" was central to the court's holding in Williams." This analysis further underscores the connection between free choice and the just distribution of entitlements that is one of the central tenets of positive freedom.

Henningsen and Williams illustrate how positive freedom invites courts to rely on arbitrary standards in deciding whether a contract is unconscionable. Courts classify certain items as "necessary adjuncts of daily life" or as "rights" and then subject the contracts associated with these items to a different standard of review to determine whether they are unconscionable. ${ }^{5 /}$ Judges rarely elaborate on the reasons why such objects qualify as entitlements. In many cases, the judges merely rely on the fact that plaintiffs are poor, lack a formal education, or are on welfare. ${ }^{5 h}$ However, these judges do not explain how any of these characteristics are connected with the ability to make rational economic decisions. ${ }^{57}$ The failure to explain this connection not only makes it difficult for later courts to apply the doctrine in a predictable and intelligible manner, but it leaves the impression that courts are relying on what can be characterized at best as mere intuition, and at worst as invidious stereotyping, as a basis for invalidating contracts.

ple of a desert oasis to illustrate his point).

53. Wright. The Courts Have Failed the Poor. NY Times at 101-02 (cited in note 30).

54 See id at 102.111.

s5 But consider Williams, 350 F2d at 450 (Danahar dissenting) (arguing that "[w]hat is a luxury to some may seem an outright necessity to others").

56 See Kugler v Romain.58 NJ 522.279 A2d 640.643 (1971) (affirming an injunction on the grounds that plaintiff's installment contract for sale of educational books was unconscionable and citing as supporting evidence of the contract's unconscionability the fact that "[p]ersons with incomes of less than $\$ 5000$ a year were favored: some buyers were welfare recipients"): Williams $v$ Walker-Thomas Furniture Co, 198 A2d 914, 916 (DC App 1964), revd, 350 F2d 445 (DC Cir 1965 ) (noting that the plaintiff received welfare benefits).

57 See Alan Schwartz. A Reexamination of Nonsubstantive Unconscionability, $63 \mathrm{Va} \mathrm{L} \mathrm{Rev}$ 1053. 1076-80 (1977) (arguing that courts should not presume incompetence from poverty because no evidence conclusively shows that poverty leads to incompetence). 
2. Free choice as contingent on the use of reason.

The courts' treatment of Section 2-302 reflects the presumption that free choice is dependent on the exercise of reason. Consider the definition of unconscionability set forth in Williams, which is the most

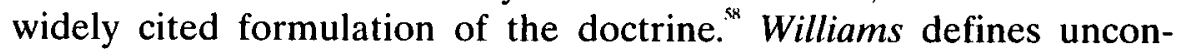
scionability as "an absence of meaningful choice on the part of one of the parties together with contract terms that are unreasonably favorable to the other party." The court explicitly refers to "absence of meaningful choice" as a criterion of unconscionability, but it fails to elaborate on what the term "meaningful" implies. Analysis of courts' application of Section 2-302 thus must first consider what constitutes a "meaningful choice."

Courts that invalidate contracts due to a lack of meaningful choice treat meaningfulness and reasonableness as largely coextensive concepts. For example, the Williams court held that the question of a contract's validity rested at least in part on the court's assessment of whether it was reasonable for the parties to enter into the transaction. ${ }^{\text {"1 }}$ Later courts draw the connection between meaningful choice and reason in more explicit terms. For example, in $A \& M$ Produce $C o$ $\checkmark$ FMC Corp, "the court held that a warranty disclaimer in a contract for a piece of farm equipment was unconscionable. The court supported its conclusion that meaningful choice was absent by noting simply that the plaintiff "would never have assented to inclusion of the term." ${ }^{\prime 2}$ The court did not consider the fact that one reason a buyer might choose a product with a warranty disclaimer is that such a product is likely to be cheaper. Rather, the court merely substituted its judgment for that of the plaintiff by means of a highly subjective conception of reasonableness.

Because courts treat reason as a necessary element for meaningful choice, it is necessary to examine the effects of the connection between reason and free choice on courts' application of Section 2-302. Consider John Murray's suggestion that a court's decision to invalidate a contract under Section 2-302 should be guided by the determi-

58 See Harry G. Prince. Unconscionability in California: A Need for Restraint and Consistency, 46 Hastings L J 459, 477 (1995) (stating that "the Williams formulation has gone on to become probably the most often-cited definition of unconscionability"). This contention is supported by an examination of the general jurisprudence regarding unconscionability. See, for example, Jones v Star Credit Corp, 59 Misc 2d 189,298 NYS2d 264, 267 (NY Sup Ct 1969) (appealing to the idea that "meaningfulness of choice [is] essential to the making of a contract" to support the conclusion that the sale of a freezer with a retail value of $\$ 300$ for $\$ 900$ was unconscionable).

59 Williams, $350 \mathrm{~F} 2 \mathrm{~d}$ at 449.

6) Id.

61 135 Cal App 3d 473, 186 Cal Rptr 114 (1982).

62 Id at 124 
nation of "what reasonable men situated as were these parties probably thought or should have thought at the time of the alleged formation." This advice clearly implies that the parameters of the doctrine of unconscionability can be ascertained by an appeal to reason. More importantly, it indicates the degree to which positive freedom, once free choice is equated with reasonable choice, requires the judge to make normative value judgments.

The problem with allowing judges to make such normative judgments is that positive freedom does not provide courts with the guidance necessary to make them in a principled manner. An examination of the cases in which courts have invalidated contracts under Section 2-302 reveals that the appeal to intuitive conceptions of fairness is most pronounced in cases where the plaintiff is a woman, poor, or the recipient of governmental aid. In Williams, Judge Wright appealed to the defendant's knowledge that the plaintiff was on welfare and had seven children as evidence of the contract's unconscionability. There is significant disagreement over Judge Wright's reasoning, even among those who support widespread use of the doctrine. ${ }^{65}$ This suggests that the value judgments that inform these decisions are not universally shared but are rather intuitive reactions to the facts of a particular case. Such decisions provide future courts with little guidance because they fail to specify a common metric to determine value. ${ }^{\text {of }}$

Positive freedom's failure to provide objective means for determining value often leads courts to rely on prejudices and stereotypes. In Williams, the court took care to point out that it "cannot condemn

63 Murray, 31 U Pitt L Rev at 11 (cited in note 4) (emphasis added).

64 Williams, $350 \mathrm{~F} 2 \mathrm{~d}$ at 448 (pointing out, as evidence of the contract's unconscionability, that "with full knowledge that [Mrs. Williams] had to feed, clothe and support both herself and seven children on [ $\$ 218$ a month in welfare], [the store] sold her a $\$ 514$ stereo set"), quoting Williams, $198 \mathrm{~A} 2 \mathrm{~d}$ at 916 . Even scholars who support widespread use of the doctrine of unconscionability evince a degree of trepidation at the conclusions generated by these normative underpinnings. Consider Muriel Morisey Spence, Teaching Williams v. Walker-Thomas Furniture Co., 3 Temple Polit \& Civ Rts L Rev 89, 95 (1993).

65 Compare David Rolewick, Note, Unconscionability under the Uniform Commercial Code-Two Trends in Cases Decided on Unconscionability Grounds, 1 Loyola U Chi L J 313, 326 (1970) (arguing for the courts' continued broad interpretation of Section 2-302 and questioning whether "it [is] too surprising to suggest that a merchant should not sell a $\$ 600$ stereo to a welfare recipient with no other source of income and children to support"), with Spence, 3 Temple Polit \& Civ Rts L Rev at 95 (cited in note 64) (supporting the use of unconscionability in cases such as Williams, but stating that "a particularly disturbing assumption is that, as the mother of seven children, Williams was fiscally irresponsible in buying a stereo that cost more than twice her monthly income").

6h Because judges' subjective value judgments occasionally reflect invidious stereotypes, it is perhaps fortunate that they provide later courts with little guidance. See, for example, Kugler, 279 A2d at 643 (holding a contract for the sale of books to inner-city children unconscionable and assessing the value of the books in light of testimony that some of the books were of "no relevance to children whose unfortunate socio-economic conditions did not make them susceptible to the concepts and ideas reflected therein"). 
too strongly" the defendant's decision to sell plaintiff a stereo even though it knew that the plaintiff was on welfare and had seven children. ${ }^{\text {.7 }}$ The court did not consider, however, that from 1957, when the plaintiff made her first purchase from Walker-Thomas Furniture, until 1962, when the stereo was purchased, the plaintiff had not missed a single payment and had successfully paid $\$ 1,400{ }^{6 *}$ The court's failure to consider crucial information, such as the plaintiff's credit history, suggests that the court was operating on the erroneous assumption that a mother on welfare cannot make rational economic decisions."

The court's reasoning in Williams indicates that the examination of the question of what someone "should" have done is often performed in an ad hoc and unprincipled manner. Not surprisingly, critics charge that this interpretation of free choice invites arbitrary resolution of cases. ${ }^{71}$ The dissent in Williams picked up on this point and voiced a concern that the majority decision would impose a test of reasonableness on contracting parties that overlooked important aspects of the transaction." Skepticism over the judiciary's ability to determine what constitutes a necessity of daily life appears equally applicable to the judiciary's ability to discern what a party to a contract should have done. The fact that Section 2-302, when viewed through the lens of positive freedom, requires the court to make such normative value judgments lends credence to the criticism that the doctrine of unconscionability invites arbitrary judicial application.

In contrast, negative freedom does not define free choice with reference to reason but rather with reference to external obstacles. This minimizes the normative dimension of a court's inquiry and therefore cabins the judiciary's ability to rely on an intuitive concept of fairness.

\section{SOLUTION}

Reliance on the concept of negative freedom would address the problems associated with the use of positive freedom as a basis for

\footnotetext{
67 Williams, 350 F2d at 448, quoting Williams, 198 A2d at 916.

6x See Spence, 3 Temple Polit \& Civ Rts L Rev at 93 (cited in note 64) (describing the background facts of the case).

69 The circular nature of the courts' argument in cases involving poor plaintiffs supports this interpretation. See Schwartz. $63 \mathrm{Va} \mathrm{L} \mathrm{Rev} \mathrm{at} 1078$ (cited in note 57) (noting that the courts' approach "is circular: the party is ruled incompetent because the deal is bad, while the deal is ruled bad because the party is incompetent").

70 See, for example, Frank Darr, Unconscionability and Price Fairness, 30 Houston L Rev 1819 (1994) (examining the widespread criticism that courts apply unconscionability in an arbitrary fashion).

71 Williams, 350 F2d at 450 (Danahar dissenting) (arguing that the majority holding does not require courts to distinguish between luxury goods and income-producing goods in their decision to hold a contract "unconscionable").
} 
applying Section 2-302 in two related ways. First, negative freedom allows clear precedent to develop by clearly defining the relevant category of criteria by which a court should evaluate free choice. Second, negative freedom limits courts' ability to decide cases based on intuitive conceptions of fairness. Furthermore, the application of unconscionability based on negative freedom is distinguishable from traditional common law defenses to contractual enforcement such as duress and fraud.

\section{A. Unconscionability Analysis Should Focus on Negative Freedom}

Use of negative freedom to determine when a contract is unconscionable would prevent the ad hoc resolution of conflicts and thus provide a coherent body of case law. As Part I.B illustrated, positive freedom's equation of free choice and reason produces intractable difficulties in determining whether free will is present.

As such, positive freedom relies on a concept of the will that first, provides courts with no substantive guidance as to what constitutes a free choice; and second, requires courts to engage in normative value judgments to determine what constitutes a free choice.

In contrast, negative freedom relies on a conception of the will that does not require the court to make normative value judgments. This is due to the fact that negative freedom does not define free choice with reference to reason. As a result, a court relying on the concept of negative freedom to apply the doctrine of unconscionability is forced to analyze a limited set of facts rather than to simply refer to the contract as unreasonable. This significantly lessens the possibility of inconsistent and unintelligible applications of Section 2-302.

Negative freedom cabins judicial discretion by removing the judge's ability to classify the subject matter of a contract as a "necessity" and consequently subject the terms of the contract to a heightened degree of judicial scrutiny. In Larned v First Chicago Corp, ${ }^{27}$ the court held that a $\$ 58$ finance charge on a credit card balance was not unconscionable. In reaching this conclusion, the court looked at the general character of the market for credit cards rather than at plaintiff's personal characteristics." The court noted that "the fact other credit card companies do provide similar benefits demonstrates that [the plaintiff] did not lack meaningful choice." Similarly, in Brunsman $v$ DeKalb Swine Breeders, ${ }^{75}$ the court held that a disclaimer of a warranty in a contract for hogs was not unconscionable based on an

72264 Ill App 3d 697, 636 NE2d 1004, 1006 (1994).

73 Id.

74 Id.

$75 \quad 138$ F3d 358 (8th Cir 1998). 
evaluation of the character of the market rather than on the personal characteristics of the plaintiff. ${ }^{76}$ In both Brunsman and Larned the court sought to determine whether the buyer had a free choice by looking to the overall character of the market.

Although the court engaged in a similar examination of the market in Henningsen, Larned and Brunsman are distinguishable because in both cases the court did not inquire whether the good in question was a necessity that should be subject to a higher standard of judicial scrutiny. This methodology is consistent with the definition of coercion under negative freedom, which limits coercive acts to physical restraint or direct acts by other individuals. The absence of competition among sellers, which was the source of concern for the courts in Larned and Brunsman, could indicate concerted action among sellers and would therefore qualify as a violation of free choice under negative freedom. The court in Henningsen could have reached a similar result by focusing solely on the question of possible collusion among car manufacturers to employ warranty disclaimers. The reference to cars as necessities of modern life, however, vitiates any clear principles that could be drawn from the court's market analysis. The failure of the Henningsen court to provide clear guidance illustrates how the limitations imposed by negative freedom on the factors courts can legitimately consider in evaluating a contract facilitates the development of clear precedent.

Courts will be more explicit in their holdings if they are required to base their decisions on external sources of coercion rather than on the mental processes of the parties. This explanatory burden is important in instances where other consumer protection legislation is better suited to the task. Surprisingly, it is often the case that courts employ the doctrine of unconscionability in cases where another specific statute is clearly applicable." Negative freedom would encourage courts to use alternative means of striking down contracts by raising the burden in cases where courts would have to stretch to apply the doctrine of unconscionability. In this respect it would most effectively cabin the

76 Id at 360 (upholding the lower court's dismissal of a claim that a disclaimer of health and fitness in a contract for boars was unconscionable and noting that the plaintiffs were "free to go elsewhere for breeding stock").

77 See American Home Improvement, Inc v Maclver, 105 NH 435, 201 A2d 886, 888 (1964) (holding the contract to be in violation of a state disclosure statute and, in the alternative, to be unconscionable). American Home was the first case involving unconscionability decided under the UCC. Although the court employed unconscionability only as an alternative ground for its holding, American Home signaled the beginning of a general trend to use unconscionability to protect consumers. See Deutch, Unfair Contracts at 118 (cited in note 9) (noting that although unconscionability was part of a commercial code "designed primarily to prevent unfairness in merchant-to-merchant contracts," the doctrine "has developed into a major tool for consumer protection"). 
use of the doctrine in marginal cases - that is, where the court would have a hard time proving that free choice was absent and where other consumer protection legislation is applicable.

\section{B. Distinction from Common Law Doctrines}

The doctrine of unconscionability, applied under the negative conception of freedom, would differ from doctrines such as fraud or duress. Courts could find contracts unconscionable in situations where the formal elements of fraud or duress were not present. Consider, for example, a case similar to Henningsen, where a seller is confronted with a standard-form contract that contains a warranty disclaimer. Also assume that there are no extenuating circumstances, making a duress claim tenuous, and that the seller does not make any false or misleading claims, making a fraud claim impossible. Unconscionability, predicated on a negative concept of liberty, could invalidate a contract under these circumstances if there was evidence of collusion among the sellers. Collusion would constitute a limit on free choice under negative freedom because an agreement among the sellers would constitute direct human interference.

\section{CONCLUSION}

The doctrine of unconscionability, embodied in Section 2-302 of the UCC, is based on a positive concept of freedom. However, positive freedom is not a suitable basis for the application of Section 2-302. Positive freedom encourages courts to engage in an ad hoc resolution of cases because it advances a concept of the will that equates free choice with reasonable choice. Negative freedom provides a better basis for application of Section 2-302 because it limits courts' discretion in applying the doctrine of unconscionability and therefore allows clear precedent to develop.

78 The requirement of a "direct" act by another individual flows from the definition of coercion under negative freedom. See Berlin, Two Concepts of Liberty at 34 (cited in note 27) ("Coercion implies the deliberate interference of other human beings within the area in which I could otherwise act."). 


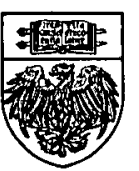

